\title{
Gothic Christians in Constantinople: The Arians
}

\author{
Mirón Jurík \\ (Masaryk University, Brno)
}

\begin{abstract}
This paper deals with the topic of Christian Goths in Constantinople, who, at the turn of the 4th to the 5th century, played an important role in the history of religious matters in the city. A significant part of these were of Arian confession, which was forbidden as heresy from the ascension of Theodosius I. Thanks to the Nicene Christian authors who actively fought Arianism, we are able to reconstruct the development of the Arian Gothic community in Constantinople and its most distinguished members. The topic of Nicene Goths in Constantinople will be presented in a follow-up paper, to be published in the next issue of Graeco-Latina Brunensia.
\end{abstract}

\section{Keywords}

Goths; Arians; Gainas; John Chrysostom; Constantinople; Homoians 
The development of the Roman policy in the second half of the 4 th and 5 th century was (among other things) determined by the growing influence and presence of the Goths on the Roman territory. After 376 when Gothic tribes crossed the Danube and their later victory over Romans in 378 at Hadrianopole, the Goths began to play an important role in the shaping of Roman history. The intensity and extent of military clashes between the specific Gothic groups and the Roman army led to the creation of federate treaties as well as the practice of hiring groups of warriors, which were then relocated to different sites of the Empire. It is only natural that Constantinople as the main, wealthy, powerful, and multicultural city of the Roman East, attracted these barbarians. The influx of Gothic people was also determined by their ambitious leaders, who had tried to gain the best possible status, wealth, influence, and contacts in the political centre of the Empire. At the turn of the 4th and 5th centuries, it became evident that Constantinople and its vicinity harboured thousands of Goths who, in the eyes of the indigenous inhabitants, represented a dangerous minority. It is intriguing that many of these Goths were Christians who built and shaped several Christian communities and confessions at the place. This paper focuses on Arians, a significant part of these Gothic Christians, the development of Arian community, and its relationship with the representatives of the Nicene creed.

\section{The Goths and Arians in Constantinople at the end of the 4th and beginning of the 5 th century}

The heretical tenets followed by the so-called "Arian Goths" are called Homoianism in modern research. The main principle was the refutation of the Greek non-biblical terminology, especially the word oúria, whereas the relationship between Christ and God was formulated as the Son being similar (ö $\mu$ oเoৎ) to the Father. ${ }^{1}$ The origin of the Gothic Arians is related to the Christianizing activity of Wulfila and the mass conversion of the Tervingi Goths in $376 .^{2}$ We also know that the treaty of 382 (foedus) was made with this group of Goths. At the same time, the sources do not reflect that these Goths were led by any unequivocal leader between years 382-392. However, the treaty in 382 may have been made between several reiks, ${ }^{3}$ Theodosius I. (379-395) and Gratian (375-383). In this treaty, the Goths were not referred to as clearly defeated, which is apparent from the fact

1 In this paper I use the terms Arian and Homoian as synonyms. For the widely-held and problematic perception of everything that can be thought of as the Arian confession, see Hanson (1988: 931 p.); for the developments of the Homoian confession in barbarian context, see Heil (2014).

2 Zeiller (1918: p. 452); Zeiller's approach is well attested by the analysis of Heather (1986: p. 315), with which I agree; however, there are other concepts of conversion of the Goths to Christianity, see: Thompson (1966: pp. 78-93); Schäferdiek (1979: pp. 90-97); Rubin (1981: p. 53); Lenski (1995: pp. 85-86); Bednaříková (2013: p. 79).

3 In this paper I use the term reiks for the old tribal aristocracy, not in the sense of the latin term rex with which it later merges. In the 4th century, the reiks did not mean the thiudans (king) yet. Vulfila used the reiks in his translation for the members of Sanhedrin or for the rich landowners. On the other hand, thiudans meant king in the monarchical sense, e.g. the Christ is called thiudans Iudaie. Wolfram (1975: pp. 16, 297, 304). 
that according to the treaty they were not scattered to the different cities and locations of the Roman Empire, as it had been usual for the settling of defeated barbarians before. On the contrary, every subgroup ( $\varphi \bar{v} \lambda \eta \dot{\eta}, k u n i)$ with its own leader was assigned a territory, which was a very important factor in the preservation of their tribal and Gothic identity. ${ }^{4}$ This identity could be supported by the relative freedom in religious matters. ${ }^{5}$ Although the Goths became the subjects of the Empire, the laws against the Arians were valid only for the citizens of the State. The federate treaty provided them with an autonomous position thanks to which they did not have to be bound by the legal regulations issued at the imperial court. ${ }^{6}$ Theodosius was forced to grant them this extraordinary freedom by the unfavourable political circumstances. In 378, during the battle of Hadrianopole, the Goths destroyed a great part of Roman army in the eastern part of the Empire. Paradoxically, such a loss of forces was later to be replaced by the members of the victorious part, i.e. the Goths themselves. Even if Theodosius was able to completely defeat the Goths, the time and expense of such an enterprise would have put a great load on the Empire. Therefore, the ideal solution for the Romans was to treat Goths as allies rather than enemies. This opportunity presented itself during the turbulent and escalating situation at the Danube border. The benefits of this solution were proven by the events that followed, including the usurpations of the Magnus Maximus and Eugenius, who were defeated thanks to the barbarian troops. A part of these Homoian Goths led by the reiks probably settled in Constantinople and its vicinity. Barbarian leaders were also frequently present at the embassies and banquets of the imperial court, with the pomp and richness naturally attracting other members of their community. ${ }^{7}$ One of these banquets was supposed to have happened in the context of the preparations for the military campaign against Eugenius. ${ }^{8}$ At the same time, Theodosius used to begin his campaigns with the whole army from Constantinople. ${ }^{9}$ As part of fulfilling their military duties, the army, which the Goths provided for the Empire, had to be concentrated

4 Heather (1991: pp. 173-175, 191) in the context of the treaty of 382: Themistius did not mention only one leading person of the Goths, he speaks about multiple leaders. Them. Or. 16. 209d-210a; the conciliation with Goths in 382 is also described by stressed compassion of Theodosius I. in the Synesius work De regno, Heather (1988: pp. 155-156); for an outline of the treaty, see Wolfram (1988: pp. 133-134).

5 Arians and other heretics were repressed and expelled from the churches inside the city wall CTh. 16.5.6; regarding the tolerant religious practice towards the barbarians, this could have been mentioned in the second canon of Constantinopolitan council: Eclesiam autem Dei in barbaricus gentibus constitutas gubernari convenit iuxta consuetudinem, quae est patribus instituta. Alberigo et al. (1962: pp. 27-28), the interpretation of this canon is questionable and it can signify the aspect of the organization of the barbarian churches, not the freedom of the keeping of their theological-heretical position. R. Mathisen believes that a barbarian bishop was not the bishop of the city, but the bishop of gentes, which can be regarded an anomaly in the organization of the churches in this respect. Mathisen (1997: p. 668): the truth is that sources until the reign of Justinian I. do not reflect any intervention of the State to suppress the Arianism of barbarians who were the subjects of the Empire.

6 See Heather (1996: p. 137).

7 Eunap. fr. 59.

8 Heather (1991: p. 186).

9 Sozom. HE. 7.24.; before he leaves Constantinople for the campaign against Eugenius, the text mentions that the greater part of his army was made up of the barbarians from the Danube region. 
near Constantinople. The sources also mention ambitious barbaric individuals who were attracted to the wealth of the imperial court and enrolled themselves to the ranks of scholae Palatinae. Another part of barbarians, especially the young generation, settled as hostages in many cities of Asia Minor. This group of hostages acted as a guarantee that the federate treaty of 376, which allowed all the Gothic tribes enter the Roman territory, would be respected. During the crisis that took place later, these hostages were massacred by commander Julius. ${ }^{10}$ Although the source states that all of them fell victim, it is probably not true. In the following years, we can still see the presence of Goths in the cities of Asia Minor, which indicates that not only could some Goths be kept alive, but also other Goths were brought in to re-settle these areas. This suggests that Thedosius I. followed a similar policy as Valens. The settlements of captivi of Odotheus, who are described as the main source of Tribigild's army, ${ }^{11}$ probably represented a modification of the same policy that might have included Constantinople. ${ }^{12}$ On the other hand, clashes with barbarian groups were supposed to provide enough Gothic slaves to serve at the houses of the lower stratum of the Roman society in Constantinople. ${ }^{13}$

The presence of the Goths in the main city could evoke a variety of passions and their Arian beliefs might have intensified a negative sentiment among the representatives of the Nicene creed. In this context, we find attempts from the side of those in power to convert Goths to the "right" way of Christianity. The sources that deal with these efforts provide us only with few glimpses into the Arian church in Constantinople. Just like the other heretics, Arians had to hold their masses outside the city wall. The Constantinopolitan Arian Goths, from the standpoint of the Church organization, fell under the supervision of Wulfila and, after his death in 383 , Selenas. ${ }^{14}$ The seat of these bishops was apparently in the vicinity of the city of Nicopolis and Haemus Mountains, where the refugees had been settled from the first persecution in Gothia. The sources recognize them as Gothi minores, a community which still existed in the 6th century $\mathrm{CE} .{ }^{15}$ It is here where Wulfila translated the Bible into the Gothic language, trained new priests, and practiced missionary activities among the Goths on both sides of the border of the Empire. It seems that he and Selenas held the power of the Church, or at least religious influence over the Gothic Arians, who entered the Empire in 376 and then made a treaty in 382. Selenas, thanks to the close connection with Wulfila, was a respected figure, whereas Selenas was

10 Amm. 31.16.8; Zos. 4.25-26; Zuckerman (1991: p. 485); Julius: comes et magister equitum et peditum per Orientem in 371-378. Jones \& Martindale \& Morris (1971: p. 481).

11 Heather (1988: p. 156, n. 12); Wolfram (1988: p. 148).

12 Gothic monks settled at the estates of Promotus, a Roman magister militum per Thracias who defeated Odotheus, in Constantinople, Jo. Chrys. Ep. 207; Doležal (2008: pp. 286-287).

13 Synesius. De Reg. 23C.

14 Sozom. HE. 7.17; Wulfila died in Constantinople and his funeral was witnessed by many citizens of Constantinople, probably also by the Goths who lived there. Aux. Epistula de fide, vita et obitu Wulfilae. Ed. Kauffmann (1899: p. 62).

15 Jord. Get. 267; Aux. Epis. 58-60; the Goths, who still lived and used the Gothic language in the 9th century in the Balkan provinces, were probably descendants of Gothi minores, see Wolfram (2013: p. 26); PL 114.927. 
equally well-educated and able to preach both in Greek and Gothic in churches. ${ }^{16}$ It is very likely that he had several times been present in Constantinople, where he could use his preaching and language skills. The links between the church representatives of the main city and the Arian Goths were close. It seems that Constantinople even regarded the Church in Gothia as a daughter Church. ${ }^{17}$ Selenas, as the one of the Thracian bishops and bishop of Goths, fell under the supremacy of the Homoian patriarch in Constantinople, who at this time, even after his deposition and expulsion, was represented by Demophilus. On the other hand, apart from Demophilus who held the ultimate authority, the Constantinopolitan Arian Goths were also obedient to Selenas. This is indirectly confirmed by a schism, which happened among the Arians after the death of Demophilus in 386, when according to Selenas' instruction, the Goths took the side of the bishop Marinus. ${ }^{18}$ However, Selenas only guided his Gothic co-believers in the matters of theological controversy. Therefore, he pointed them out to the person towards whom they, and he himself, should be obedient in religious matters. Wulfila, the predecessor of Selenas also derived his religious authority from the Constantinopolitan patriarch's supremacy. On the one hand, he himself was consecrated as a bishop by Eusebius of Nicomedia; on the other hand, he performed his missionary activities among the Goths in cooperation with another Constantinopolitan Arian bishop, Eudoxius. ${ }^{19}$ For these reasons we should think of the so called "Gothic Arian Church" as an integral part of a broader system of Homoian churches. This was not a specific barbarian issue for the eastern part of the Empire, not even after 380, when Homoians formally ceased to represent the state Church. The Arian Church acquired a distinctly barbaric character, although not completely, in the western part of the Empire, where the barbarians formed their kingdoms under the dominance of Arians. This happened in an environment, where the different kinds of a subordinate theology never gained such support as in the east. The migration of the Goths to the west led by Alarich and his successors should be seen as the main factor in the "infection" of the western provinces with the Homoian creed.

Nevertheless, the Arianism may have helped to strengthen a separate identity of the Constantinopolitan Goths. Besides their participation in the masses with Greco-Roman Arian believers outside the city wall, they probably held separate meetings in churches or tents, in which they celebrated masses in the Gothic language. After all, the prerequisites for the existence of the sacred scriptures in the Gothic language and the trained staff for these positions had already been fulfilled in 380s. One participant at these

16 Sozom. HE. 7.17.

17 Before the Demophilus' ordination as the patriarch in Constantinople, he was the bishop of Beroia in Thrace. In this office, he was Wulfila's neighbor to the south and he certainly belonged to his closest contacts. Schäferdiek (1991: pp. 42, 47).

19 Theodor. HE. 4.37; Sozom. HE. 6.37; however, the text of Theodorethus is chronologically confusing, the part about the instructions for Vulfila is given in the context of the crossing of the Danube in 376 , the 6 years after the death of Eudoxius. This reference better fits the events of Gothic-Roman war in 367-369 and especially Wulfila's Christianization, which led to the second persecution of Christians in Gothia. 
meetings was Gainas, the Gothic magister militum who had the ambition to defend, by his authority, the interests and needs of the Arian community in Constantinople.

It is well known that Gainas requested a church for the Arians as a reward for his merits. As the military commander, whose army consisted mainly of barbarians, he invoked a sense of danger in Arcadius (383-408), which is why the emperor was willing to accept his demands. He was also able to find the support of Caesarius in this matter, but after a vigorous intervention of the orthodox patriarch John Chrysostom, who reminded Gainas that the honour and wealth provided by the Empire are sufficient rewards, this endeavour failed. ${ }^{20}$ Nevertheless, it was proposed that the so-called "Church of the Goths" that was burnt together with the asylum seekers during the famous massacre of the Goths, may have been used by Gothic Arians in service (thanks to Caesarius), at least for a while, and that the intervention of John Chrysostom had only a short-term effect. ${ }^{21}$ I rather agree with Kelly who argues that Synesius's text about Caesarius' efforts has been misinterpreted and it, in fact, refers to what Caesarius set himself to bring about without any implication about his success. ${ }^{22}$ It is obvious that the church of the Goths, which was assigned to Gothic community in Constantinople, served the orthodox purpose. This is because it would be unacceptable, if the church of the Paul in which John presented his Homilia habita postquam presbyter Gothicus concionatus fuerat, was the same as "the Church of the Goths" provided to the Arians. There is no doubt that John would never provide them the church with remains of Paul, former Nicene bishop of Constantinople and the great fighter against the Arians. ${ }^{23}$ The destruction of the church meant the end of the efforts to convert the Arian Goths to the Nicene confession, and it also showed that its concept was not understood by the population of Constantinople. ${ }^{24}$

Despite Gainas' failure in his request for the church, we can derive many facts about the Arian Gothic community from his activities. It seems that Gainas was not only a high-ranking soldier in the Roman army, but also a political leader of a relatively large group of Goths. The sources point out that the main body of his army comprised of Goths. The fact that he was perceived as such by Romans, as well, is confirmed by the massacre of the Gothic community in 400 , which was supposed to be a reaction to his uprising and occupation of Constantinople. ${ }^{25}$ His army had a strong barbarian character,

20 Theodor. HE. 5.32.; Sozom. HE. 8.4; Synesius. De Prov. 115B.

21 Synesius. De Prov. 115B; Liebescheutz (1990: pp. 190-191); according to Doležal the church was assigned for the purpose of the Gothic Arian community by John Chrysostom himself, Doležal (2008: p. 283).

22 Kelly (1995: pp. 157-158); see also: Albert (1984: pp. 156-158); Cameron \& Long \& Lee (1993: pp. 327-328); Schäferdiek (2006: pp. 289-290).

23 Sozom. HE. 8.4; Socr. HE. 6.6; Zos. 5.19; Jo. Chrys. Hom. 8; Marcell. chron. (399) XII: fugientes ecclesiae nostrae succedunt.

24 Albert (1984: p. 176).

25 Gainas held several military titles. As comes (comes rei militaris), he is described in 399 by Jordanes. Jord.

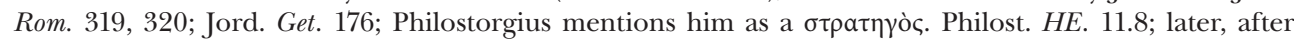
the treaty with Arcadius in Chalcedon, he gets the title of magister utriusque militiae. Sozom. HE. 8.4; it is evident that he had political authority as a leader of the Goths who inhabited Constantinople and its vicinity. It is not testified only by the fact of the Roman perception of the uprising, which was perceived as barbaric, not as an usurpation of a leader of a specific army in the common sense (even with the barbarian 
even during the time when he was setting out against Tribigild, i.e. before the Goths of Tribigild joined him. ${ }^{26}$ From the perspective of the sacral rule ${ }^{27}$ of the barbarian societies and the above-mentioned request of the church for Arians, it may appear that he felt responsibility for his co-believers and improve their social status, despite his justification of the fact by his merits only. The sources, moreover, reveal that the questions of faith were truly important to him. This is proved by the correspondence he maintained with Nilus of Ancyra. Unfortunately, the letters sent by Gainas to Nilus have been lost. However, from Nilus' responses it is obvious that the main subjects of their discussions were the basic theological issues, especially the relationship between Christ the Son and God the Father. ${ }^{28}$ Nilus, as a representative of Nicene creed, was very critical and reproving towards the Roman commander on the grounds of his Homoian confession. He even dared to call him and his co-believers "destroyers of the Christ's flock" ${ }^{29}$ From two particular letters $(79,286)$ it appears that Nilus reacted to some arguments from Sacred Scripture, which Gainas used in his reasoning. Therefore, it seems that he was well aware of the parts of the Bible which strengthened his theological position, although the letter 114 informs that he did not know how to write, thus, requiring help from the educated and orthodox people. The rhetoric of Nilus seems to be a rather paternalistic and several letters disclose his fear that his word will never truly be heard. Nevertheless, it is apparent from the correspondence that he also felt some respect towards Gainas and hoped that he could gain him for the "true" faith. ${ }^{30}$ It is quite intriguing that Gainas, although possibly illiterate, was open to discussion and interested in the opinions of a Nicene monk and a disciple of John Chrysostom. We should see this correspondence as a part of John Chrysostom's efforts who tried, in cooperation with Nilus, to convert Arian Goths to the Nicene faith. In this context, the exaggeration of the church historian about the Gainas' respect towards John might have had a historical basis exactly in his openness to discussion. ${ }^{31}$

Among other things, Gainas confirms the fact that veneration of the cult of Saints among the Arians was evolving. In the case of the martyrs who lived before the Arian

leader, compare Arbogast), but also by the fact that he was a leader of the part of the allied Gothic army in the battle of the Frigidus. Zos. 4.57.2, 4.58; Joh. Ant. fr. 212.2; people, who used to be political leaders of tribes, were in the leading positions of these barbaric troops. These were the people who were trusted by their tribesmen and retinue, such as Fritigern, Alaric, Sarus, or Saul. As for Gainas, this fact can be confirmed by the drawings of Arcadian column, where not only soldiers, but also women and children, are depicted as prisoners, although to a little extent; the flight of the Gothic civilians from Constantinople, among them women and children, who felt evidently threatened because of their affiliation to Gainas is supported also by Synesius. De Prov. 117B.

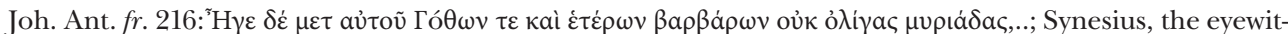
ness of the massacre in Constantinople, defines him as a general of the foreign troops who had his home in the royal city. Synesius. De Prov. 108B; a dating of Synesius' stay in Constantinople during these events is certain in both cases, whether it was in 399-402 (Seeck 1894) or 397/398-end of 400 (Barnes 1986).

27 For the barbaric sacral rule see Bednaříková (2015: pp. 23-34).

28 Nil. Ep. 79, 115, 116.

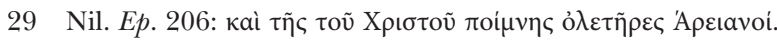

30 Nil. Ep. 70, 79, 114-116, 205-206, 286.

31 Theod. HE. 5.33. 
schism, we can see an overlap in the veneration of the fighters of faith among Nicene and Arian Christians. One example of such an overlap could be represented by the meeting of Arcadius with Gainas in Chalcedone that took place in the chapel of the martyr Euphemia. It was here, above the remains of the female saints, where they swore an oath not to conspire against each other. However, given the context of the following events, church historians believe that Gainas broke this oath, despite the fact that we do not know all the details of the treaty (we only know he was appointed as magister utriusque militiae), including who actually broke it first. On the other hand, neither Arcadius was able to keep the agreement, as we can see in Gainas' request for the church. However, this matter could be just one of many parts of the unfulfilled agreement. The account of Sozemenus implies that the assignment of the church occurred exactly between the treaty of Chalcedon and Gainas' coup. At the same time, it appears that Gainas' appointment as magister utriusque militiae ${ }^{32}$ was merely a superficial gesture and that he had no real power over certain military units in Constantinople. Except for the incident at the gates, when his troops passed through, this is reflected by the presence of the imperial troops guarding the palace and their subsequent significant involvement in the massacre of Goths. In this respect, the guards were not only a part of scholae Palatinae, considering that Gainas himself was very surprised by the presence of these militants, who were described as a miraculous help from heaven (according to the church historians), but also another part of Roman military units. We may assume that the presence of the scholae Palatinae would not be unexpected by him. ${ }^{33}$ He could have perceived the unfulfillment of his own ambitions and the disregard shown for the terms of the treaty from Chalcedon as a breaking of the oath, to which he was, thus, no longer bound. The next example of his veneration of the saints is found in his alleged possession by a demon, a pretext he used for the visiting of the chapel of Saint John the Baptist. Whether a pretext or not, this activity was not supposed to have surprised anyone, and in the context of his religious behaviour it must have seemed natural. The chapel was located at Hebdomos, where Theodosius I. had prayed before the campaign against Eugenius and where, at the time of the battle, it was believed there was a miracle. Gainas, as a fellow soldier in the campaign and battle of the Frigidus, witnessed the Emperor's piety and devotion at the Chapel of Saint John the Baptist, which could have seemed to him as a factor leading to his victory. While it can be said that Gainas put on a play at the chapel, it may also be argued that it was a sincere effort to secure a supernatural help for his worsening situation. ${ }^{34}$ Considering his true interest in the religious issues, as it is proved by the corre-

32 Probably praesentalis Jones \& Martindale \& Morris (1971: p. 379); according to Notitia dignitatum, MVM praesentalis $I$. had in his military units the Visi, and MVM praesentalis II. had also units as Tervingi, Scythae. Not. dign. or. 5, 61; or. 7, 44, 61.

33 Socr. HE. 6.5; Sozom. HE. 8.4; according to Eunapius' mocking fragment about a certain Perses, the following massacre was presented as a miraculous intervention of God, as well. Cameron \& Long \& Lee (1993: pp. 218ff); Eunap. fr. 68.

34 Sozom. HE. 7.17; Theodosius I. put in this place the head of the St. John the Babtist. Sozom. HE. 7.21; the church at Hebdomos was visited for the purpose of prayer by Epiphanius, before he entered Constantinople, which underlines the importance of this location. Sozom. HE. 8.14; Socr. HE. 6.13; the veneration of the saints among the Gothic-Arians is also testified by the calendar, in which the names of the several 
spondence with Nilus, and his respect towards John Chrysostom, this can be considered a plausible interpretation.

Due to the abovementioned, it is not surprising that Gainas, a religious person as well as a political leader of the Gothic community in Constantinople, thought of himself as an important person in guaranteeing the religious needs of the people loyal to him. His engagement in the securing of the church and the fact that he and his people, at the incentive of Selenas' side of Psathyrians, imply an extremely tight link between the authority of a secular ruler and the church among the barbarians, which manifests itself even more clearly in the later barbarian kingdoms. ${ }^{35}$ This results in a question of how the Constantinopolitan Goths perceived Gainas? Despite the fact that he did not belong to the reiks, who arrived onto Roman soil years before, as well as his humble origin, he might have been perceived as one of the reiks. Even though we are unable to reconstruct the exact circumstances that led to this situation, it is clear that he, as one of the leaders of the barbaric army, must have been perceived in a similar way as reiks at least in the battle of the river Frigidus. Commanders of the barbaric armies were usually kings, respectively political leaders, at the same time, and the trust between them and the troops willing to fight side by side with Romans was crucial. Since the old tribal structures were dissolving in the new reality of the Roman Empire, the leader, and how he dealt with Romans, was very important. Gainas's dexterity, his successes, wealth, and career at imperial court were perceived by the barbarians as a blessing from God, which certainly strengthened the tendencies of the Sacral rule.

The Gainas and other Constantinopolitan Goths also played an active role in the split of the Arian Church at the end of the 4th century. The schism that took place among the Arians in 386 illustrates some theological outlets of the Arian Goths. This strife had begun after the death of the already mentioned Demophilus, when Marinus from Thrace succeeded him. However, after only a short time, Marinus was deposed and replaced by Dorotheus of Antioch, who was considered more competent by many Arians ${ }^{36}$ The controversy between Marinus and Dorotheus was also manifested at the theological level, namely the question, whether it should be possible to call the God a Father even before the existence of a Son. Marinus believed that the Father had always been the Father, whereas according to Dorotheus, before the existence of the God - the Son, it would not be appropriate. The resulting strife led to the expulsion of Marinus and his followers from the Arian churches. After that they built their own places of worship and started to be marked as the Psathyrians or the Goths. They were named Goths due to

saints are mentioned, among them the apostles Philipus and Andrew, but also the Arian bishop Dorotheus. The story about Gaatha, the Gothic princess, who transferred the remains of 26 martyrs, is also linked to the calendar. Delehaye (1912: p. 279); a presence of the remains of the common venerated saints, both for Nicene and Arian Christians, could have overcome confessional barriers in special situations, typically for the purpose of praying. The respect towards the remains of the saints, even though they were placed in the Nicene churches, is testified by the conduct of Alaric who, during the plundering of Rome, ordered not to loot the churches with the remains of St. Peter and Paul and to respect these places as asylums. Oros. 7.39.1; see also Synesius. De Prov. 111B. 
the fact that the theological position of Marinus was supported by the Gothic bishop Selenas and by many of the barbarians, mainly from the Gothic population of Constantinople. ${ }^{37}$ Although a distinctive Gothic element representing the Psathyrians could have strengthened the separate identity of the Gothic community, it was not actually a specific church of the Goths. A new split emerged after a short time in the form of a power struggle between Marinus and Agapius (who had been ordained as a bishop in Ephesus by Marinus). According to the church historians, the Goths took the side of Agapius. The definitive end to the schism among the Arians occurred some 35 years later. The reconciliation of the quarrelling sides was resolved by Plintha, an Arian and a consul who was of the Gothic origin, too. ${ }^{38}$ Plintha's reference to this matter represents the last mention of the Psathyrians, although he was himself a member of the sect before the reconciliation. Plintha's reference testifies that the community of Psathyrians was still maintained even after the massacre of Goths and that the barbarian heretics in the service of the Empire were approached benevolently. Plintha was even trusted by the State and, on a few occasions, he even involved himself in the dealings of the church. ${ }^{39}$

At the first sight, it may seem that all Arian Goths were Psathyrians or followers of Agapius; however, the reality was more complicated. A part of the Goths probably followed Dorotheus, since the name Daurithaius aipiskaupaus was listed, among other saints, on a fragment of a Gothic calendar for November $6^{\text {th }} .{ }^{40}$ Presumably, the calendar refers to the above-mentioned bishop who deposed Marinus. The fact that he was perceived as a saint in the following generations implies that a relatively important group of Goths must have followed him and maintained his veneration. Whether Barba, his successor and the last known Arian bishop of Constantinople, was originally a Goth is still debated. ${ }^{41}$

\section{Conclusion}

The evolution of the Arian Goths on the turn of the 4th and 5th centuries in Constantinople was very intricate. Gothic believers were also shattered together with the Arian church. One part of the Goths started to follow Dorotheus, the other Marinus, whereas the third group followed Agapius. Based on the sources, it seems plausible that most of the Constantinopolitan Goths joined the Psathyrians. However, we cannot really speak

37 Sozom. HE. 7.17; Socr. HE. 5.23.

38 Socr. HE. 5.23; Sozom. HE. 7.17; the strife had to be settled in 419 under Plintha's consulate, who held his office with Flavius Monaxius, not the Emperor.

39 ACOec. I.IV. s. 88; Martindale (1980: p. 893).

40 Delehaye (1912: p. 275).

41 Zeiller (1918: p. 523); Schäferdiek (1988: pp. 131-132); Loewe (1922: pp. 271-272); Heather \& Matthews (1991: p. 122, n. 64); it is necessary to mention that it can be Dorotheus of Tyre who was sent into the exile during Diocletian's persecution and was persecuted during the reign of the Emperor Iulianus Apostata. According to Martyrologium Romanorum he was listed on the $5^{\text {th }}$ of June. Caraffa \& Morelli (1964: pp. 829-830). 
of a "special" Gothic Arian church in Constantinople. Although the Goths fell under the church jurisdiction of the bishop Selenas, who was seated in the vicinity of Nicopolis, they were likewise under the authority of the Constantinopolitan Arian patriarchs, who were obeyed by Selenas as a higher power in the Church hierarchy. On the one hand, we may think of Selenas' power over the Gothic Arians in Constantinople at the nominal level. On the other hand, we should also take into consideration the presence of the Gothic presbyters, the liturgy in the Gothic language, and the churches, serving the needs of this special and populous minority of Constantinople. In the principle, however, Goths formed an integral part of the local Arian Church. The previously mentioned splits and power struggles among the Arians were probably, according to the Nicene historians, the reasons for the transition of many clerics and believers to the Nicene confession. ${ }^{42}$ It can be an exaggeration but the attempt to convince a Gothic leader who had a great impact on his people, shows that these tendencies were supported by the representatives of the Nicene Constantinopolitan episcopal see.

\section{Bibliography}

\section{Primary Sources}

Alberigo, J. et al. (Eds.). (1962). Conciliorum oecumenicorum decreta (2 ${ }^{\text {nd }}$ ed.). Basel: Herder.

Blockley, R. C. (Ed.). (1983). The Fragmentary Classicising Historian of the Late Roman Empire. Eunapius, Olympiodorus, Priscus and Malchus (Vol. II). Liverpool: Francis Cairns.

Delehaye, H. (1912). Saints de Thrace et de Mésie. Analecta Bollandiana, 31, 161-300.

Heather, P., \& Moncur, D. (Transl.). (2001). Politics, Philosophy and Empire in the Fourth Century: Select Orations of Themistius. Liverpool: Liverpool University Press.

Kambylis, A., \& Mariev, S. (2008). Corpus Fontium Historiae Byzantinae. Ioannis Antiocheni fragmenta quae supersunt omnia (Vol. 47). Berlin - New York: De Gruyter.

Kauffmann, F. (Ed.). (1899). Texte und Untersuchungen zur altgermanischen Religionsgeschichte. Strassburg: K. J. Trübner.

Mendelssohn, L. (Ed.). (1887). Zosimus: Historia nova. Lipsiae: B. G. Teubner.

Migne, J. P. (Ed.). (1852). Patrologia Latina (Vol. 114). Lutetia Parisiorum: Migne.

Migne, J. P. (Ed.). (1864). Patrologia Graeca (Vol. 66). Lutetia Parisiorum: Migne.

Migne, J. P. (Ed.). (1864). Patrologia Graeca (Vol. 67). Lutetia Parisiorum: Migne.

Migne, J. P. (Ed.). (1864). Patrologia Graeca (Vol. 82). Lutetia Parisiorum: Migne.

Migne, J. P. (Ed.). (1865). Patrologia Graeca (Vol. 79). Lutetia Parisiorum: Migne.

Mommsen, T. (Ed.). (1882). Iordanis Romana et Getica. Berolini: apud Weidmannos.

Mommsen, T. (Ed.). (1894). Chronica Minora (Vol. II). Berolini: apud Weidmannos.

Mommsen, T., \& Kruegeri, P. (Eds.). (2011). Codex Theodosianus. Theodosiani libri XVI cum constitutionibus Sirmondiandis (Vol. 1). Hildesheim: apud Weidmannos.

Schwartz, E. (Ed.). (1965). Acta conciliorum oecumenicorum, T. I: Concilium Universale Ephesenum,

42 Socr. HE. 5.23; Sozom. HE. 7.17, 8.1. 
Vol. IV: Collectionis Casinensis sive synodici a Rustico diacono compositi pars altera. Berlin - Boston: De Gruyter.

Seeck, O. (Ed.). (1876). Notitia dignitatum: Accedunt notitia urbis Constantinopolitanae et laterculi provinciarum. Berolini: apud Wiedmannos.

Seyfarth, W. (Ed.). (1978). Ammianus Marcellinus: Res Gestae (Vol. II). Leipzig: B. G. Teubner.

Zangemeister, C. (Ed.). (1882). Corpus scriptorum ecclesiasticorum Latinorum, 5: Paulus Orosius. Vindobona: Gerold.

\section{Secondary Sources}

Albert, G. (1984). Goten in Konstantinopel. Paderborn: Ferdinand Schöning.

Barnes, T. D. (1986). Synesius in Constantinople. Greek, Roman and Byzantine Studies, 27, 93-112.

Bednaříková. J. (2013). Stěhování národů. (3rd. ed.) Praha: Vyšehrad.

Bednaříková, J. (2015). Contribution to the Basic Methodological Questions (Ancient States and the States in the Transitional Period between Antiquity and Middle Ages). In J. Bednaříková, M. Meško, \& A. Žáková (Eds.), On Research Methodology in Ancient and Byzantine History (pp. 9-38). Brno: Masaryk University.

Cameron, A., Long, J., \& Lee, S. (1993). Barbarians and Politics at the Court of Arcadius. Oxford: University of California Press.

Caraffa, F., \& Morelli, G. (1964). Bibliotheca Sanctorum. Romae: Pontificia Università Lateranense. Doležal, S. (2008). Interakce Gótů a řimského impéria. Praha: Karolinum.

Hanson, R. P. C. (1988). The Search for the Christian Doctrine of God. The Arian Controversy, 318-381. Edinburgh: T\&T LTD.

Heather, P. (1986). The Crossing of the Danube and the Gothic Conversion. Greek, Roman and Byzantine Studies, 27, 289-318.

Heather, P. (1988). The Anti-Scythian Tirade of Synesius' "De Regno". Phoenix, 42(2), 152-172.

Heather, P. (1991). Goths and Romans 332-489. Oxford: Clarendon Press.

Heather, P. (1996). The Goths. Oxford: Blackwell Publishers Ltd.

Heather, P., \& Matthews, J. (1991). The Goths in the Fourth Century. Liverpool: Liverpool University Press (repr. 2004).

Heil, U. (2014). The Homoians. In G. M. Berndt, \& R. Steinacher (Eds.), Arianism: Roman Heresy and Barbarian Creed (pp. 85-115). Farnham - Surey - Burlington: Ashgate.

Jones, A. H. M., Martindale, J., \& Morris, J. (1971). The Prosopography of the Later Roman Empire (Vol. I.). Cambridge: Cambridge University Press.

Kelly, J. (1995). Golden Mouth: The Life of John Chrysostom. New York: Cornell University Press.

Lenski, N. (1995). The Gothic Civil War and Date of the Gothic Conversion. Greek, Roman and Byzantine Studies, 36, 51-87.

Liebescheutz, J. H. W. G. (1990). Barbarians and Bishops: Army, Church, and State in the Age of Arcadius and Chrysostom. Oxford: Clarendon Press.

Loewe, R. (1922). Der gotische Kalender. Zeitschrift für deutsches Altertum und deutsche Literatur, 59 , 245-290.

Martindale, J. R. (1980). The Prosopography of the Later Roman Empire (Vol. II). Cambridge: Cambridge University Press. 
Mathisen, R. W. (1997). Barbarian Bishops and the Churches "in Barbaricis Gentibus" during Late Antiquity. Speculum, 73, 664-697.

Rubin, Z. (1981). The Conversion of the Visigoths to Christianity. Museum Helveticum, 38, 34-54.

Schäferdiek, K. (1979). Zeit und Umstände des westgotischen Übergangs zum Christentum. Historia, 28, 90-97.

Schäferdiek, K. (1988). Das gotische liturgische Kalenderfragment - Bruchstück eines Konstantinopeler Martyrologs. Zeitschrift für die neutestamentliche Wissenschaft und die Kunde der älteren Kirche, 79, 116-137.

Schäferdiek, K. (1991). Gotien: eine Kirche im Vorfeld des frühbyzantinischen Reichs. Jahrbuch für Antike und Christentum, 33, 36-52.

Schäferdiek, K. (2006). Johannes Chrysostomos und die ulfilanische Kirchensprache. Zeitschrift für Kirchengeschichte, 117(2/3), 289-296.

Seeck, O. (1894). Studien zu Synesios. Philologus, 52, 442-483.

Thompson, E. A. (1966). The Visigoths in the time of Ulfila. Oxford: Clarendon Press.

Wolfram, H. (1975). Gotische Studien I, II. Mitteilungen für österreichische Geschichtsforschung, 83, $1-32,289-324$.

Wolfram, H. (1988). History of the Goths (transl. T. J. Dunlap; $1^{\text {st }}$ ed.). Berkeley: University of California Press.

Wolfram, H. (2013). Vulfila pontifex ipseque primas Gothorum minorum. In A. Kaliff, \& L. Munkhammar (Eds.), Wulfila 311-2011. International Symposium, Uppsala University, June 15-18, 2011 (Acta Bibliothecae R. Universitatis Upsaliensis; pp. 25-32). Uppsala: Uppsala University.

Zeiller, J. (1918). Les origines chrétiennes dans les provinces danubiennes (Bibliothèque des Ecoles Françaises d'Athènes et de Rome, 112). Paris: De Boccard.

Zuckerman, C. (1991). Cappadocian Fathers and the Goths. Travaux et Mémoires, 11, 473-486.

Mgr. Mirón Jurík / 466660@mail.muni.cz / mironjurik@gmail.com

Department of Classical Studies

Masaryk University, Faculty of Arts

Arna Nováka 1, 60200 Brno, Czech Republic

This work can be used in accordance with the Creative Commons BY-SA 4.0 International license terms and conditions (https://creativecommons.org/licenses/by-sa/4.0/legalcode). This does not apply to works or elements (such as image or photographs) that are used in the work under a contractual license or exception or limitation to relevant rights 
